\title{
Pattern Of Meals and Sedentary Lifestyle with Obesity Events In Junior High School Students In Limboto
}

\author{
Rahmawati ${ }^{1}$, Saifuddin Sirajuddin ${ }^{2}$, Suci Herdiyanti Said ${ }^{3}$ \\ \{rahma.amma97@gmail.com ${ }^{1}$, saifuddin59@yahoo.com², sucihsaid16@gmail.com ${ }^{3}$ \} \\ Doctoral Program Hasanuddin University, Perumahan Mutiara Kita C12 Limboto ${ }^{1}$, \\ The Faculty of Public Health, Kompleks Hartaco Permai ${ }^{2}$ \\ Gorontalo University, Molibagu, Bolaan Mongomdow Selatan ${ }^{3}$
}

\begin{abstract}
Obesity is a condition of excessive accumulation of body fat which can interfere with health. Riskesdas 2013 data on the prevalence of obesity in adolescents according to BMI / U, Indonesia 10.8\%, where from 33 provinces the highest obesity in East Kalimantan was $17.0 \%$, and the lowest in NTT province was $3.0 \%$. This study used an analytical survey with cross-sectional study design, with a sampling technique of proportional stratified random sampling. The sample in this study were 314 junior high school students. The results of the study used the chi-square test of diet $\rho$ value $0.717>\alpha$ $=0.05$, which means that there was no significant relationship between diet and the incidence of obesity in junior high school students in Limboto district, Gorontalo district, sedentary activity $\rho$ value $0.010<\alpha=0.05$, which means there is a significant relationship between sedentary activity and the incidence of obesity in junior high school students in limboto sub-district, Gorontalo. Teenagers can increase physical activity to avoid obesity.
\end{abstract}

Keywords: Pattern Of Meals, Sedentary Lifestyle, Obesity

\section{Introduction}

Obesity is a multifactorial disease that occurs due to the accumulation of excessive fat tissue; obesity is a complex disorder of appetite regulation and energy metabolism that is controlled by several specific biological factors. Physiologically, obesity is defined as a condition with abnormal or excessive fat accumulation in adipose tissue so that it can interfere with health. Obesity is usually expressed in the presence of $25 \%$ of total body fat in men and as much as $35 \%$ or more in women [1]. According to the WHO, 2.8 million people die in the world each year due to obesity. According to a survey conducted by the National Cancer Institute in America, as many as $4 \%$ of cancers in men and $7 \%$ of cancers in women are associated with obesity, for example, breast cancer, endometrial cancer, and colon cancer. Based on data from Riskesdas 2013, obesity prevalence in adolescents according to BMI / U, age 13-15 years in 33 provinces of Indonesia is $11.0 \%$, of which 33 provinces are the highest obesity in East Kalimantan $17.0 \%$ and the lowest in NTT province $3.0 \%$. Whereas the highest obesity prevalence in adolescents aged 16-18 years was DKI 5.0\% and the lowest was in West Sulawesi province at $1.0 \%$.

Based on 2013 Riskesdas, the proportion of physical activity classified as less active in general was 26.1 percent. There are 22 provinces with a population of physical activity 
classified as less active above the Indonesian average. The proportion of the Indonesian population with sedentary behavior $\geq 6$ hours per day is 24.1 percent. The five provinces above the national average are Riau (39.1\%), North Maluku (34.5\%), East Java (33.9\%), West Java (33.0\%), and Gorontalo (31.5\%).

In 2017 based on the preliminary study taken randomly, in each Limboto District Junior High School (SMP) there were 98 students of whom experienced cases of obesity. The results of the 2016 Sulaeman Mentari study, that sedentary behavior and food consumption (FFQ) are the causes of obesity in high school (SMA) students [2]. Where OR values $(6,755)$ of sedentary activity and face food, the incidence of obesity was obtained by OR values $(6,152)$. Based on this background, the purpose of this study was to determine the relationship of diet, and sedentary activity with the incidence of obesity in junior high school students in Limboto District.

\section{Materials and Methods}

The type of research used is analytic survey research using a cross-sectional study design, namely the study design to see the relationship of independent variables that include diet and sedentary with the dependent variable that is the incidence of obesity in junior high school students measured at the same time.

The population in this study were students in grades VII and VIII of junior high school students in 2011 who were in Limboto Subdistrict. The sample in this study were adolescent students of class VII and VIII of Junior High School in Limboto District with a total sample of 314 respondents.

The sampling technique used was "proportional stratified random sampling." A sampling of "proportional stratified random sampling" is done if the research unit is between strata with one another.

\subsection{Research variable.}

The Independent Variable in this study is Diet, Sedentary Activity, and Dependent Variable is the incidence of Obesity. Obesity events in this study were increasing body volume with a normal body weight with a standard deviation (> 2.0 SD) by measuring BMI according to age BMI / U. What is meant in the diet in this study is a way or effort in setting the amount and type of food in excessive diet can be a factor in the occurrence of obesity, for the needs of carbohydrate intake is enough 80 to $110 \%$ and more than $110 \%$ and the fat needs of the category enough 80 to $110 \%$ and more than $\geq 110 \%$ according to the 2013 AKG Standard. And what is meant by sedentary activity in this study is someone's behavior that shows less physical activity or less movement behavior. This sedentary behavior is classified as casual behavior. In the category, if obese students have a duration of sedentary activity that is more than 5 hours/day, whereas the students are not obese, the duration of the sedentary activity is less than 5 hours/day 


\section{Result}

Research on Diet and Sedentary Activity With the incidence of obesity in junior high school students in Limboto district, Gorontalo district in 2017, the number of respondents was 314 students, from the total population of 2,011 students in 11 schools in Limboto sub-district. Junior High School Gorontalo districts totaled 11 consisting of MTs. Limboto Model, Limboto Middle School 1, Limboto Junior High School 2, Limboto Junior High School 3, Limboto Junior High School 4, Limboto Junior High School 5, Limboto Middle School 6 , Limboto Junior High School, Limboto Junior High School 8, Limboto Junior High School 9, MTs. Nuruttaqwa.

Distribution of respondents based on age, gender, the incidence of obesity, carbohydrate intake, fat intake, diet, and sedentary activities can be seen in table 1 below:

Table 1. Distribution of respondents based on age, gender, the incidence of obesity, carbohydrate intake, fat intake, diet, and sedentary activities in students in the Limboto junior high school

\begin{tabular}{|c|c|c|}
\hline Age & $\mathbf{N}$ & $\%$ \\
\hline 12 & 8 & 2.5 \\
\hline 13 & 122 & 38.9 \\
\hline 14 & 166 & 52.9 \\
\hline 15 & 17 & 5.4 \\
\hline 16 & 1 & 0.3 \\
\hline Total & 314 & 100 \\
\hline \multicolumn{3}{|l|}{ Gender } \\
\hline Male & 121 & 38.5 \\
\hline Female & 193 & 61.5 \\
\hline Total & 314 & 100 \\
\hline \multicolumn{3}{|l|}{ Obesity } \\
\hline Obesity & 213 & 67.8 \\
\hline Non Obesity & 101 & 32.2 \\
\hline Total & 314 & 100 \\
\hline \multicolumn{3}{|c|}{ Carbohydrate intake } \\
\hline Adequate & 151 & 48.1 \\
\hline Over & 163 & 51.9 \\
\hline Total & 314 & 100 \\
\hline \multicolumn{3}{|l|}{ Fat intake } \\
\hline Adequate & 54 & 17.2 \\
\hline Over & 260 & 82.8 \\
\hline Total & 314 & 100 \\
\hline \multicolumn{3}{|c|}{ Meals of pattern } \\
\hline Adequate & 12 & 3.8 \\
\hline Over & 302 & 96.2 \\
\hline Total & 314 & 100 \\
\hline \multicolumn{3}{|c|}{ Sedentary activity } \\
\hline Low & 22 & 7.0 \\
\hline High & 292 & 93.0 \\
\hline Total & 314 & 100 \\
\hline
\end{tabular}


Of the 314 respondents, the most age was distributed at the age of 14 years as much as $52.2 \%$, for sex the most distributed in female sex as much as $61.5 \%$, for the incidence of obesity in respondents as much as $67.8 \%$ of respondents who were obese. The highest intake of food in the form of carbohydrate intake was distributed in the sufficient category (51.9\%), for the fat intake respondents were distributed the most in the more category $(82.8 \%)$, while the diet most respondents were distributed in the more category (96.2\%). For sedentary activities, most respondents were distributed in the high category (93\%).

Tabel 2 Bivariate analyst between diet, sedentary activity with obesity events in junior high school students in Limboto district

\begin{tabular}{|c|c|c|c|c|c|}
\hline \multirow[t]{2}{*}{ Variable } & \multicolumn{2}{|c|}{ Obesity } & \multicolumn{2}{|c|}{ Non-Obesity } & \multirow[t]{2}{*}{$\mathbf{p}$} \\
\hline & $\mathbf{N}$ & $\%$ & $\mathbf{N}$ & $\%$ & \\
\hline $\begin{array}{l}\text { Meals of } \\
\text { pattern }\end{array}$ & 8 & 66.7 & 4 & 33.3 & 1.000 \\
\hline $\begin{array}{l}\text { Adequate } \\
\text { Over }\end{array}$ & 205 & 67.9 & 97 & 32.1 & \\
\hline Aktivitas & & & & & 0.010 \\
\hline Sedentary & 9 & 47.4 & 13 & 59.1 & \\
\hline $\begin{array}{l}\text { Low } \\
\text { High }\end{array}$ & 204 & 69.2 & 88 & 30.8 & \\
\hline
\end{tabular}

\section{Discussion}

Obesity is a multifactorial disease, which results from excessive accumulation of fat tissue; obesity is a complex disorder of appetite regulation and energy metabolism that is controlled by several specific biological factors. Physiologically, obesity is defined as a condition with the accumulation of fat

Abnormal or excessive adipose tissue so that it can interfere with health. Obesity is usually expressed in the presence of $25 \%$ of total body fat in men and as much as $35 \%$ or more in women. In school children and adolescents, the incidence of obesity and obesity is a serious problem because it will continue into adulthood. It is indicated by the standard deviation $\mathrm{z}$ score (> 2.0 SD) with BMI measurements according to age BMI/Age [1].

All obese students are in MTs schools. Limboto's model is as many as 93 students $(29.6 \%)$, for students aged 14 years, there are 166 students (52.9\%), while based on gender, more girls who are obese are 193 students $(61.5 \%)$, so it can be seen that there is still a high incidence of obesity at the junior high school level.

This is in line with Gorontalo Regional 2013 Riskesdas data, the prevalence of obesity in adolescents according to BMI / U. age 13-15 years as much as 11.0\%, and ages 16-18 years as much as $3.0 \%$. So, the research is done to look at diet (carbohydrate intake, fat intake), and sedentary activities. For more details, the results of the study are discussed according to the variables studied as follows:

Meals of Pattern, Excessive eating patterns can be a factor in obesity. Obesity occurs when a person consumes calories more than the number of calories burned. In essence, the body needs calorie intake for survival and physical activity, but to maintain body weight, there needs to be a balance between incoming energy and energy that comes out. The energy balance that occurs can lead to overweight and obesity [3]. Based on Table 1 shows that of the 314 respondents, the highest dietary pattern was the diet that was $302(96.2 \%)$. 
Table 2 shows that of the 12 samples for dietary patterns that were sufficiently seen in the incidence of obesity, the most distributed among obese students was $8(66.7 \%)$. While of 302 samples for the most widely distributed diet for obese students 205 (67.9\%).

Based on data analysis by using chi-square statistical test with a significant level of $\alpha=$ 0.005 in table 2 there is no relationship between diet and the incidence of obesity by looking at the value of $\rho$ value $(1,000>\alpha 0.05)$ means there is no significant relationship between diet and incidence of obesity in junior high school students in the District.

This research is in line with Miko (2017) [4], From the results of the calculation of statistical tests using chi-square test in getting results, there is no relationship between diet and nutritional status in the Acehnese students, where $\mathrm{p}=0.769$.

Research Results Rizka at.al explained the relationship between eating patterns and the incidence of obesity using the chi-square test of nutrients showed that carbohydrate intake in perolen $\mathrm{p}=0.202$ and fat intake was obtained $\mathrm{p}=0.437$ [5].

All junior high schools in Limboto sub-district are more dominant in having more eating patterns, because they prefer fast food sold at each school canteen so that it affects the weight of each student, but the results show no relationship between diet and obesity because this obesity is chronic from previous eating habits, but researchers only do a 24 hour recall where the intake obtained only shows the current one.

Sedentary Activity, Childhood obesity is predicted to be associated with inactive habits that lead to sedentary behavior. Sedentary behavior hurts health. Currently, sedentary behavior becomes an important issue in public health. Sedentary behavior is a group of behaviors that occur when sitting or lying down which requires very low energy expenditure, such as sitting or lying down while watching television, playing electronic games, reading, and so on.

Based on Table 1 shows that of the 314 samples that were distributed the most in the group of frequent sedentary activities where the nutritional status of obesity students $204(69.2 \%)$ and not obese $91(30.9 \%)$, while the lowest distribution was obtained in the group of sedentary activities rarely where are the nutritional status of $9(47.4 \%)$ and non-obese $10(52.6 \%)$, obese students.

Based on table 2, chi-square statistical test analysis with a significant level of $\alpha=0.005$ obtained the value of $\rho$ value $(0.010>\alpha 0.05)$ means that there is a significant relationship between sedentary activity with the incidence of obesity of junior high school students in limboto district.

Teens with less active, sedentary activity are likely to be obese because subjects who are less active will find it very difficult to burn fat in their bodies. Based on the results of the stratification test also known that the effect of less active activity with high energy intake on obesity (4 times) was higher than the effect of highly active physical activity with high energy intake on obesity. It is stated that less active activities will have different effects with highly active physical activity on increasing food intake and the incidence of obesity. Activities that are less active with high energy intake will have a greater risk of obesity. In each Junior High School (SMP) in Limboto District, the average student has sedentary activities (casual activities) such as playing cellphone, games, hanging out. Without doing activities such as exercise, the results show that there is a relationship between sedentary activity and the incidence of obesity in junior high school students. The results of the study of Octavian also get a long-time watching television $(\mathrm{p}=0.037)$ related to the incidence of obesity in high school students.

The results of Nurul Istiqamah's research obtained bivariate analysis using the chi-square test obtained p-value $<0.05$ so that there was a relationship between a sedentary lifestyle and the incidence of central obesity and central obesity [6]. Alam (2007) stated that sedentary 
lifestyle, low physical activity coupled with a poor diet that is high in fat and carbohydrates (fast food) that is not balanced with fiber (vegetables and fruit) in sufficient quantities, makes accumulating fat with symptoms of being overweight (obesity), especially in the abdomen (distended) [7]. The impact of central obesity is higher on health risks compared to general obesity [8]. Central obesity is also associated with cardiovascular disease and coronary heart disease [9]. In Finnish studies, the prevalence of overweight and obesity has increased among children and adolescents, and also in adults, and watching television has been proposed as one of the causes of this [10]. Low physical activity is positively associated with obesity in women but not in men [11]. Physical activity is one of the factors that can increase energy demand so that if physical activity is low, the probability of obesity will increase [11].

\section{Conclusion}

Generally adolescents have high sedentary activity, which can directly affect the incidence of obesity. For this reason, teenagers are expected to live actively with various extra-curricular activities that exist both at school and outside of school

\section{References}

[1] Mokolengsang, G, Olivia, Manampiring, E, Aalje ,Fatmawati.: Hubungan Pola Makan Dan Obesitas Pada Remaja Di Kota Bitung. Jurnal : E-Biomedik (Ebm) Vol.14 pp,128-135 (2016)

[2] Suleman, Mentari. :Skripsi UG Faktor Risiko Kejadian Obesitas Pada Remaja Siswa SMA Negeri Se - Kabupaten Gorontalo Tahun 2016 pp. 23-30 (2016)

[3] Aflah, Ruhul, Rizka ; Indiasari, Rahayu ; Yustini.: Hubungan Pola Makan Dengan Kejadian Obesitas Pada Remaja Di Sma Katolik Cendrawasih. Repository.Unhas.Ac.Id Di Akses Pada Tanggal 5 Januari 2017. pp. 33-40 (2014)

[4] Ampera Mico,Melsy pratiwi.: Hubungan Pola Makan dan Aktivitas Fisik dengan Kejadian Obesitas Mahasiswa Politeknik Kesehatan Kemenkes Aceh, Action Aceh Nutrition Journal. Vol.2.pp. 1-5 (2017)

[5] Rizka Ruhul Aflah , Rahayu Indiasari, Yustini. Hubungan Pola Makan Dengan Kejadian Obesitas Pada Remaja Di Sma Katolik Cendrawasi.

[6] Nurul Istiqamah, Saifuddin Sirajuddin, Rahayu Indriasari. Hubungan Pola Hidup Sedentarian Dengan Kejadian Obesitas Sentral Pada Pegawai Pemerintahan Di Kantor Bupati Kabupaten Jeneponto pp. 23 (2013)

[7] Alam, S.. Gagal Ginjal, Jakarta, PT. Gramedia Pustaka Utama. Pp,120-133 (2007)

[8] Shen, W., Punyanitya, M., Chen, J., Gallagher, D., Albu, J., Pi-Sunyer, X., Lewis, C. E., Grunfeld, C., Waist Circumference Correlates with Metabolic Syndrome Indicators Better Than Percentage Fat. Vol.14.pp.727-36 (2006)

[9] Baik, I., Ascherio, A., Rimm, E. B., Giovannucci, E., Spiegelman, D., Stampfer, M. J. \& Willett, W. C.: Adiposity and Mortality in Men. American Journal of Epidemiology, Vol.152, pp. 264-271 (2000)

[10] Kautiainen, S., Koivusilta, L., Lintonen, T., Virtanen, S. M. \& Rimpelä, A.: Use of information and communication technology and prevalence of overweight and obesity among adolescents. International journal of obesity, Vol.29, pp. 925-933 (2005)

[11] Soegih, R. R. \& Wiramihardja, K.. Obesitas.: Permasalahan Dan Terapi Praktis. Pp.112 (2009) 